\title{
Omalizumab in chronic spontaneous urticaria treatment: Real life experiences
}

\author{
Kronik spontan ürtiker tedavisinde omalizumab: Gerçek yașam verisi
}

๑ Burhan Engin, ๑ Uğur Çelik*, ๑ Aslıhan Özge Birben, ๑ Özge Așkın, ๑ Zekayi Kutlubay, ๑ Server Serdaroğlu

İstanbul University-Cerrahpașa, Cerrahpașa Faculty of Medicine, Department of Dermatology, İstanbul, Turkey *ìstanbul Șișli Hamidiye Etfal Training and Research Hospital, Clinic of Dermatology, İstanbul, Turkey

\begin{abstract}
Background and Design: Urticaria is an intensely pruritic dermatologic disorder characterized by temporary erythematous and edematous lesions. Immunoglobulin E (IgE), mast cells, and histamine play a major role in its pathogenesis. $H_{1}$ antihistamines are the basis of the treatment, but they may not be sufficient for some cases. The latest guidelines advise using omalizumab, anti-lgE monoclonal antibody, for patients with refractory urticaria. Our aim was to evaluate the efficacy and safety of omalizumab in patients with chronic spontaneous urticaria and share the reallife experiences in our patients.

Materials and Methods: This study, which covers the 50 months between April 2014 and June 2018, includes data of 124 chronic spontaneous urticaria patients treated with monthly subcutaneous injections of omalizumab. The 7-day urticaria activity score (UAS7) was used to compare the disease severity before and after the treatment.

Results: A total of 124 patients, consisting of 75 females (60.4\%) and 49 males (39.6\%), were enrolled. The mean UAS7 scores before and after the treatment were 32.4 and 2.8, respectively. Before the treatment, 107 of 124 patients (86.2\%) had severe urticaria, while the remaining 17 patients (13.8\%) had a moderate disease. Urticarial lesions of 78 patients (63\%) completely disappeared under treatment. Thirtyone patients (25\%) had the disease under control. Twelve patients (9.6\%) still had mild disease, and the remaining three patients $(2.4 \%)$ had moderate refractory symptoms. There was no correlation between treatment response rates and the presence of thyroid autoantibodies or high IgE levels. There was no severe side effect observed during the treatment of up to 36 months (mean 11 months).

Conclusion: Our results supported the literature showing that omalizumab is a rapid-acting, effective, and safe treatment choice for chronic spontaneous urticaria.
\end{abstract}

Keywords: Anti-lgE, chronic spontaneous urticaria, histamine, mast cell, omalizumab

Öz

Amaç: Ürtiker, geçici eritemli ve ödemli lezyonlarla karakterize, yoğun kaşıntılı dermatolojik bir hastalıktır. Immünoglobulin E (IgE), mast hücreleri ve histamin patogenezinde önemli rol oynar. $\mathrm{H}_{1}$ anti-histaminikler tedavinin temelidir, ancak bazı durumlarda yeterli olmayabilir. Son kılavuzlar dirençli ürtikeri olan hastalar için anti-lgE monoklonal antikoru olan omalizumab, kullanımını önermektedir. Amacımız kronik spontan ürtiker hastalarında omalizumabın etkinliğini ve güvenliğini değerlendirmek ve hastalarımızdaki gerçek yaşam deneyimlerini paylaşmaktır. Gereç ve Yöntem: Nisan 2014 ile Haziran 2018 arasında 50 ayı kapsayan bu çalışma, aylık subkütan omalizumab enjeksiyonları ile tedavi edilen 124 kronik spontan ürtiker hastasının verilerini içermektedir. Tedavi öncesi ve sonrası hastalık şiddetini karşılaştırmak için 7 günlük ürtiker aktivite skoru (ÜAS7) kullanılmıştır.

Bulgular: Toplam 124 hastadan $75^{\prime} i$ kadın $(\% 60,4)$ ve $49^{\prime}$ u erkek $(\% 39,6)$ idi. Tedavi öncesi ve sonrası ortalama ÜAS7 skorları sırasıyla 32,4 ve 2,8 idi. Tedavi öncesi 124 hastanın 107'sinde $(\% 86,2)$ şiddetli ürtiker, 17'sinde (\%13,8) orta derecede hastalık vardı. Tedavi edilen 78 hastanın (\%63) ürtikeryal lezyonları tamamen kayboldu. Hastaların 31'i (\%25) kontrol altındaydı. On iki hastada $(\% 9,6)$ hala hafif bir hastalık vardı ve

Address for Correspondence/Yazışma Adresi: Burhan Engin MD, İstanbul University-Cerrahpaşa, Cerrahpaşa Faculty of Medicine, Department of Dermatology, istanbul, Turkey Phone: +90 5334981945 E-mail: burhanengin2000@yahoo.com Received/Geliş Tarihi: 28.11.2018 Accepted/Kabul Tarihi: 15.05.2019 ORCID: orcid.org/0000-0002-5140-1926 


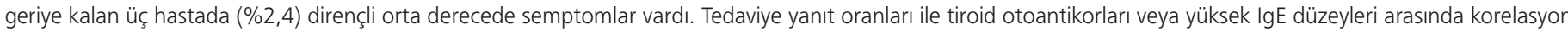
yoktu. Tedavi sırasında 36 aya kadar (ortalama 11 ay) ciddi bir yan etki görülmedi.

Sonuç: Sonuçlarımız omalizumabın kronik spontan ürtiker için hızlı etkili, etkin ve güvenli tedavi seçeneği olduğunu gösteren literatürü desteklemektedir

Anahtar Kelimeler: Anti-lgE, kronik spontan ürtiker, histamin, mast hücresi, omalizumab

\section{Introduction}

Urticaria is a common dermatologic disorder which is characterized by pruritic, erythematous and edematous lesions on any part of the body. The prevalence of urticaria is $10-20 \%$ in general population but it is approximately $1 \%$ for its chronic form, which means the disease longer than six weeks ${ }^{1,2}$. The disease may be idiopathic, autoimmune or inducible. There are many triggering factors such as medications, infections, foods, emotional stress or physical factors. It is difficult to determine a specific cause in chronic cases ${ }^{3}$.

Characteristic feature of this eruption is to be transient which means an individual lesion disappears in one day without leaving any clue but repetitive manner is troublesome for most of the patients In pathogenesis of this allergic reaction, immunoglobulin $\mathrm{E}(\operatorname{IgE})$, cutaneous mast cells and their main content, histamine plays major role ${ }^{4}$.

$\mathrm{H}_{1}$ anti-histamines are the basis of the treatment but they are not sufficient in a considerable ratio of patients, even with approved high doses (four fold of routine daily dosage). Latest guidelines advise to use omalizumab, cyclosporine or leukotriene receptor antagonists for cases refractory to high dose anti-histamines ${ }^{5}$. Omalizumab is a recombinant, humanized monoclonal antibody which acts via binding free IgE in serum and preventing its interaction with high affinity immunoglobulin E receptor (FcERI) receptors on mast cells. We aimed to evaluate the efficacy and safety of omalizumab in patients with chronic spontaneous urticaria and share the real life experiences in our patients.

\section{Materials and Methods}

This is a retrospective study of 124 patients with chronic, refractory urticaria treated with omalizumab between April 2014 and June 2018. Omalizumab was preferred for patients whose diseases were refractory to various doses of multiple anti-histamines or high doses (up to four fold of routine daily dosage) of the particular one. Some of these patients had also used the third line therapies according to the treatment guideline.

Anamnesis and physical examination were mostly adequate for diagnosis of urticaria. In addition to demographic data such as patients' age and sex, personal and family history of allergic diseases (such as asthma, atopic dermatitis, allergic rhinitis, urticaria and angioedema), age of onset and duration of the disease were recorded.

Laboratory examinations were used to find out possible causes such as infections or any systemic diseases, especially autoimmune ones. We used complete blood count, fasting blood glucose, liver and kidney function tests, eritrocyte sedimentation rate, C-reactive protein, $C_{3}$ and $\mathrm{C}_{4}$ levels, antinuclear antibody, romatoid factor, thyroid hormones and autoantibodies, total serum IgE levels, viral serology, urinalysis, fecal parasite examination and Helicobacter pylori antigen in stool samples. Omalizumab was administered by subcutaneous injections at doses 300 mg every four weeks. During the treatment, patients were followed up by the same physician to determine effects and side effects. Disease severity was evaluated before and after the treatment by urticaria activity score (UAS) and its weekly total, UAS7. UAS is a scoring system used to assess severity of urticaria by questioning intensity of pruritus and number of wheals in one day during a week. As indicated in Table 1, UAS consists of the sum of each score (0 to 6). The weekly UAS7 could be calculated by summing daily scores over seven consecutive days. As shown in Table 2, higher scores indicate more severe disease ${ }^{5}$. According to the responses to omalizumab, patients were grouped as follows: no urticaria (UAS $=0$ and no increase in symptoms during follow-up), under control (UAS=1-6), mild disease (UAS=7-15), moderate disease (UAS=15-27) or severe disease (UAS=2842) at follow-up.

Since there is no specific risk for a serious side effect, there is no recommendation for routine laboratory examinations in patients using omalizumab. We used laboratory tests only in patients with side effects, according to symptoms.

Patients were informed before the study. Informed consent was obtained from patients before omalizumab treatment and all patients approved to participiate in the study.

\section{Statistical Analysis}

The descriptive statistics were presented as mean for numerical variables and frequency (percent) for nominal variables. The difference between before and after treatment in the severity of disease was compared with McNemar test. The relationship between IgE level, autoantibody presence and treatment response was evaluated with Pearson correlation coefficient. All statistical analyses were performed with SPSS for Windows, version 14.01. The statistical significance level was considered as $p<0.05$.

Table 1. Daily urticaria activity score

\begin{tabular}{|l|l|l|l|}
\hline Number of wheals & Score & $\begin{array}{l}\text { Intensity of } \\
\text { pruritus }\end{array}$ & Score \\
\hline None & 0 & None & 0 \\
\hline$<20$ & 1 & Mild & 1 \\
\hline $20-50$ & 2 & Moderate & 2 \\
\hline$>50$ or large confluent areas & 3 & Intense & 3 \\
\hline
\end{tabular}

Table 2. Disease severity according to UAS7 score

\begin{tabular}{|l|l|}
\hline Disease severity & UAS7 score \\
\hline No urticaria & 0 \\
\hline Under control & $1-6$ \\
\hline Mild & $7-15$ \\
\hline Moderate & $15-27$ \\
\hline Severe & $28-42$ \\
\hline UAS7: Urticaria activity score &
\end{tabular}




\section{Results}

In this study, a total of 124 patients consisted of 75 females (60.4\%) and 49 males (39.6\%) were enrolled. The ages of patients were between 15 and 83 years (mean age: 37.3 ) while mean age of onset and mean duration of the disease were 36.1 years and 68.4 months respectively. Only 10 of the 124 patients (8\%) had a family history of allergic diseases. Twelve patients (9.6\%) had personal allergic disease history such as asthma and allergic rhinitis while 16 patients (13\%) had concurrent angioedema.

In laboratory examinations, thyroid autoantibodies were detected in 16 patients (13\%) but their thyroid hormone levels were normal. Total serum lgE levels ranged between 7 and $1420 \mathrm{IU} / \mathrm{mL}$ while 26 patients (20.9\%) had values higher than normal. The demographic features of our patients are showed in Table 3.

\section{Treatment history}

As recommended in latest guideline, we often preferred high dose of particular anti-histamine instead of using multiple anti-histamines together. All patients had been treated with $\mathrm{H}_{1}$ blocking anti-histamines up to four fold of standard therapeutic dose. An average anti-histamine usage before omalizumab therapy was 41.2 months. 33 patients (27\%) had also used systemic steroids (mean 4.7 months, intermittently, total) and 11 patients (9\%) had used cyclosporine (mean 3.1 months) but these treatments were ceased because of side effects or loss of efficacy. One patient with urticaria refractory to drugs mentioned

Table 3. Patients' demographic features

Demographic features

\begin{tabular}{|c|c|}
\hline Age, year, median & $37.3(15-83)$ \\
\hline \multicolumn{2}{|l|}{ Sex, n (\%) } \\
\hline Female & $75(60.4 \%)$ \\
\hline Male & $49(39.6 \%)$ \\
\hline Duration of disease, months & 68.4 \\
\hline Mean age of onset, year & 36.1 \\
\hline Thyroid antibodies positivity, n (\%) & $16(13 \%)$ \\
\hline Family history of allergic disease (\%) & $8 \%$ \\
\hline $\begin{array}{l}\text { Accompanying allergic diseases (astma, allergic } \\
\text { rhinitis) (\%) }\end{array}$ & $9.6 \%$ \\
\hline Accompanying angioedema (\%) & $13 \%$ \\
\hline High total serum IgE level (>100) & $26(20.9 \%)$ \\
\hline Oma injection number, median & 11 \\
\hline IgE: Immunoglobulin E & \\
\hline
\end{tabular}

Table 4 . Disease severity before $\&$ after omalizumab treatment

\begin{tabular}{|l|l|l|}
\hline Severity of disease & Number of patients \\
\hline & Before & After \\
\hline Severe & $107(90.6 \%)$ & 0 \\
\hline Moderate & $17(9.4 \%)$ & $3(2.4 \%)$ \\
\hline Mild & 0 & $12(9.6 \%)$ \\
\hline Under control & 0 & $31(25 \%)$ \\
\hline No urticaria & 0 & $78(63 \%)$ \\
\hline
\end{tabular}

above was also unresponsive to salazopyrin and dapsone treatments for three months each.

\section{Omalizumab treatment}

In this study omalizumab was administered by subcutaneous injections at doses $300 \mathrm{mg}$ every four weeks. The dose was stable for every patient. The number of the treatments ranged from 3-36 months. If the symptoms were not under control after three injections, omalizumab treatment was ceased and those patients were enrolled as refractory to omalizumab. For most of the patients, the efficacy started within one week after the first injection. The meantime of omalizumab usage was 11 months. The longest usage of omalizumab was 36 months. Some patients needed anti-histamines after three weeks from the injection until the next treatment. Some had relapsed within approximately two months after the discontinuation of omalizumab As noted in Figure 1, mean UAS7 scores before and after the six omalizumab treatments were 32.4 and 2.8 respectively. Table 4 shows distribution of the disease severity before and after omalizumab treatment using UAS7. Before the treatment, 107 of 124 patients (86.2\%) had severe urticaria while remaining 17 patients (13.8\%) had moderate disease. Urticarial lesions of 78 patients (63\%) completely disappeared under the treatment. 31 patients' (25\%) diseases were under control. Twelve patients (9.6\%) still had mild disease and remaining three patients (2.4\%) had refractory moderate symptoms. Overall omalizumab led to a decrease in the use of concomitant medications.

There was no correlation between with lgE levels and treatment response. Twenty-six patients (20.9\%) had high levels of total serum $\mathrm{IgE}$. Complete remission was evident in 16 of them (61.5\%) and this rate was compatible with the success in whole study group (63\%). Besides, two of the three patients who had refractory symptoms, had normal IgE values. Sixteen patients (13\%) had thyroid autoantibodies but their thyroid hormone levels were in normal range. There was no correlation between treatment response and autoantibody presence. In this study, no severe side effect was observed during the treatment up to 36 months (mean 11 months). Three patients (2.4\%) suffered

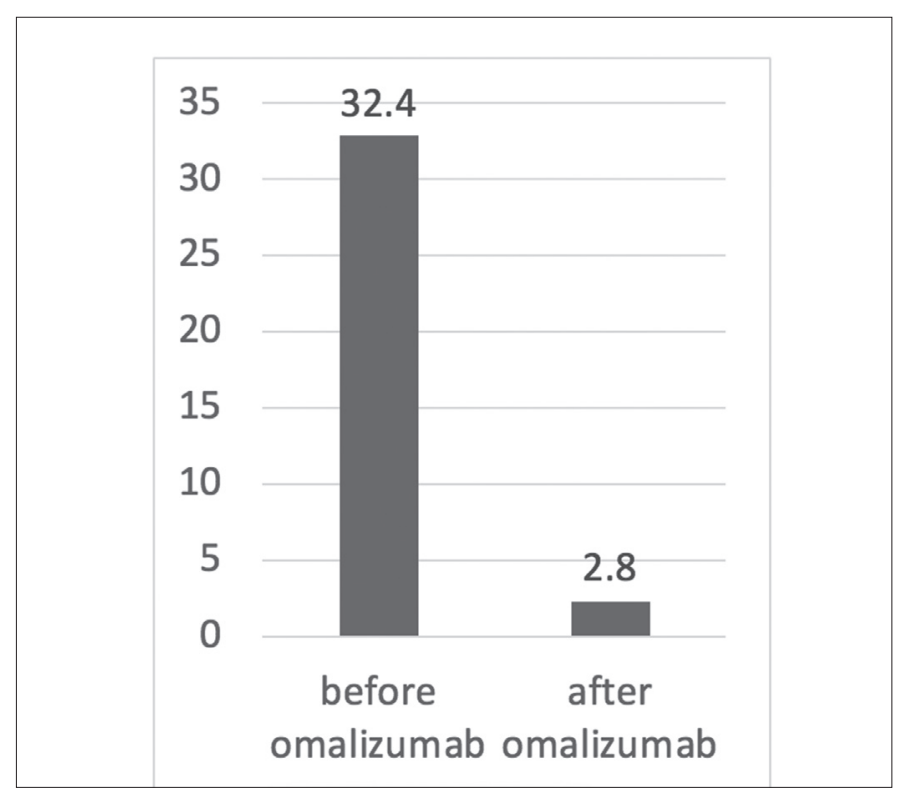

Figure 1. Mean UAS7 scores before and after UAS7: Urticaria activity score 
from headache, one patient $(0.8 \%)$ had nasopharyngitis and one patient $(0.8 \%)$ had diarrhea.

\section{Discussion}

Chronic spontaneous urticaria is associated with decreased quality of life for most of the patients ${ }^{7}$. The aim of the treatment is to control symptoms without side effects. $H_{1}$ blocking anti-histamines are the first line treatment while second-generation, non-sedative ones are preferred option ${ }^{8}$. Nevertheless, considerable ratio of the patients is unresponsive. Other treatment options such as systemic corticosteroids and cyclosporine are used in caution due to their side effect profiles. Omalizumab is an IgG1 monoclonal antibody that binds to the human IgE selectively. Omalizumab, an anti-lgE monoclonal antibody, has been recommended as an effective and safe by treatment guidelines in recent years ${ }^{5}$. Its bioavailability is $62 \%$ and achieves its maximum serum level in 7-8 days. The half-life of the drug is ranging from 3 to 4 weeks ${ }^{9}$ Although the mechanism of omalizumab is not completely understood in urticaria, it is thought to bind free IgE and reduce IgE- and FCeRImediated mast cell and basophil activation ${ }^{10,11}$.

This study aimed to evaluate the efficacy and safety of omalizumab treatment in patients with chronic spontaneous urticaria. Patients who had chronic spontaneous urticaria refractory to $\mathrm{H}_{1}$ blocking antihistamines up to four fold of standard therapeutic dose were included. About one fourth of the patients had used systemic corticosteroids during exacerbations and some patients were unresponsive to cyclosporine, salazopyrin and dapsone.

The long mean duration of the disease (68.4 months) and long average anti-histamine usage (41.2 months) observed in this study emphasized the chronic nature of the disease and need for effective and safe alternative treatments. Consistent with the view that it is difficult to determine a specific cause, the laboratory examinations did not show any remarkable abnormalities that could be attributed to disease etiology.

Omalizumab was administered by subcutaneous injections at doses 300 mg every four weeks. During the treatment, patients were followed up by the same physician to determine efficacy and safety issues. UAS7 system was used to evaluate the clinical response. In our study the rapid onset of action was recorded with omalizumab in accordance with the literature. Drug activity started mostly about one week after the first injection. Some patients needed to use additional anti-histamines especially in one week before the next injection but it was obvious that concomitant drug usage decreased significantly during omalizumab treatment. Some patients responded to treatment after the first injection, however, others needed more time to control the symptoms. In the literature, there are many patients that responded therapy after three months. So it is not recommended to stop the treatment because of inefficacy before three injections of omalizumab ${ }^{12}$. In our patients, omalizumab is applied at least three months before ceasing the treatment ${ }^{6,13,14}$. Ferrer et al. ${ }^{15}$ recommend to continue treatment for six months to decide if there is no response to omalizumab.

Omalizumab therapy is a symptomatic treatment and it has been shown that symptoms gradually returned after discontinuation of treatment ${ }^{16}$. In some of our patients relapsed within approximately two months after cessation of the treatment. It is also compatible with the other studies in the literature that the symptoms are back again mostly seen in 3 weeks to several months after stopping omalizumab. When we started the treatment again, their symptoms were resolved or decreased mostly in one week ${ }^{10,17}$.

Patients are evaluated with the urticarial acitivity score before and after the omalizumab treatment. Most of the patients had a remarkable response: 78 of 124 (63\%) achieved complete remission which is described as $U A S 7=0$. One fourth of the patients had the disease under control, 12 patients (9.6\%) had mild disease while remaining 3 patients $(2.4 \%)$ had refractory moderate symptoms. This study is in line with previous studies, and has come up with slightly better complete remission rates ${ }^{12,18}$.

The efficacy of omalizumab is thought to be independent of IgE levels, and past studies have supported this ${ }^{17,19,20}$. Similarly, in our patients no correlation was found between lgE levels and treatment response. Also the efficacy was similar to previous studies, clinical response was apparent by one week in omalizumab group. At the end of three months, complete remission rates were 5\% and 34\% respectively. Symptoms gradually returned during the observation period ${ }^{21}$.

The most common side effects reported in the literature were nausea, headache, dizziness, fatigue, and injection site reactions. No serious side effects were reported in these studies ${ }^{9}$. When we consider in terms of the drug safety, there was no serious side effect during omalizumab usage up to 36 months in our study. Headache, nasopharyngitis and diarrhea were observed in few patients but the relationship with the drug could not be clearly determined.

As a result, in this study which covers a long period such as 50 months, we observed that omalizumab is rapid acting, effective and safe treatment for chronic idiopathic urticaria. It is associated with decreased concomitant drug usage and increased quality of life. It is also shown that the response is independent of $\lg E$ levels and thyroid autoantibody presence.

\section{Study Limitation}

This is a retrospective study of 124 chronic urticaria patients.

\section{Conclusion}

Our results supported the literature showing that omalizumab is rapid acting, effective and safe treatment choice for chronic spontaneous urticaria.

\section{Ethics}

Ethics Committee Approval: Retrospective study.

Informed Consent: Patients were informed before the study. Informed consent was obtained from patients before omalizumab treatment and all patients approved to participiate in the study.

Peer-review: Externally peer-reviewed.

\section{Authorship Contributions}

Surgical and Medical Practices: B.E., U.Ç. A.Ö.B., Ö.A., Z.K., S.S., Concept: B.E., U.Ç. A.Ö.B., Ö.A., Z.K., S.S., Design: B.E., U.Ç. A.Ö.B., Ö.A., Z.K., S.S., Data Collection or Processing: B.E., U.Ç. A.Ö.B., Ö.A., Z.K., S.S., Analysis or Interpretation: B.E., U.Ç. A.Ö.B., Ö.A., Z.K., S.S., Literature Search: B.E., U.Ç. A.Ö.B., Ö.A., Z.K., S.S., Writing: B.E., U.Ç. A.Ö.B., Ö.A., Z.K., S.S.

Conflict of Interest: No conflict of interest was declared by the authors. 
Financial Disclosure: The authors declared that this study received no financial support.

\section{References}

1. Clive EH, Ruth A, Malcom W: Chronic urticaria. J Am Acad Dermatol 2002;46:645-57.

2. Gaig P, Olona M, Muñoz Lejarazu D, et al: Epidemiology of urticaria in Spain. J Investig Allergol Clin Immunol 2004;14:214-20.

3. Kulthanan K, Jiamton S, Thumpimukvatana N, Pinkaew S: Chronic idiopathic urticaria: prevalence and clinical course. J Dermatol 2007;34:294-301.

4. Tharp MD: Chronic urticaria: pathophysiology and treatment approaches. J Allergy Clin Immunol 1996;98:325-30.

5. Zuberbier $T$, Aberer $W$, Asero $R$, et al: The EAACI/GA(2) LEN/EDF/WAO Guideline for the definition, classification, diagnosis, and management of urticaria: the 2013 revision and update. Allergy 2014;69:868-87.

6. Saini $\mathrm{S}$, Rosen $\mathrm{KE}, \mathrm{Hsieh} \mathrm{HJ}$, et al: A randomized, placebo-controlled, doseranging study of single-dose omalizumab in patients with $\mathrm{H} 1$-antihistaminerefractory chronic idiopathic urticaria. J Allergy Clin Immunol 2011;128:56773.

7. Itakura A, Tani Y, Kaneko N, Hide M: Impact of chronic urticaria on quality of life and work in Japan: Results of a real-world study. J Dermatol 2018;45:96370.

8. Mignon T, van den Elzen, Harmieke van Os-Medendorp, et al: Effectiveness and safety of antihistamines up to fourfold or higher in treatment of chronic spontaneous urticaria. Clin Transl Allergy 2017;7:4

9. Göncü EK, Kızltaç K, Leslie T: Omalizumab in chronic urticaria: A comprehensive review. Turkderm-Turk Arch Dermatol Venereology 2018;52:112-9.

10. Akyol A, Öktem A, Akay BN, Kundakçı N, Boyvat A: Omalizumab and treatment-resistant chronic spontaneous urticarial. Turkderm 2015;49:180-3.
11. Tonacci A, Billeci L, Pioggia G, Navarra M, Gangemi S: Omalizumab for the treatment of chronic idiopathic urticaria: Systematic review of the literature. Pharmacotherapy 2017;37:464-80.

12. Kaplan A, Ferrer M, Bernstein JA, et al: Timing and duration of omalizumab response in patients with chronic idiopathic/spontaneous urticaria. J Allergy Clin Immunol 2016;137:474-81.

13. Hawro T, Ohanyan T, Schoepke $\mathrm{N}$, et al: Comparison and interpretability of the available urticaria activity scores. Allergy 2018;73:251-5.

14. Türk M, Yılmaz i, Bahçecioğlu SN: Treatment and retreatment with omalizumab in chronic spontaneous urticaria: Real life experience with twenty-five patients. Allergol Int 2018;67:85-9.

15. Ferrer $M$, Boccon-Gibod I, Gonçalo $M$, et al: Expert opinion: defining response to omalizumab in patients with chronic spontaneous urticaria. Eur J Dermatol 2017;27:455-63.

16. Ferrer M, Gamboa $P$, Sanz ML, et al: Omalizumab is effective in nonautoimmune urticaria. J Allergy Clin Immunol 2011;127:1300-2.

17. Metz M, Ohanyan T, Church MK, Maurer M: Omalizumab is an effective and rapidly acting therapy in difficult-to-treat chronic urticaria: a retrospective clinical analysis. J Dermatol Sci 2014;73:57-62.

18. Ferrer $M$, Boccon-Gibod I, Gonçalo $M$, et al: Expert opinion: defining response to omalizumab in patients with chronic spontaneous urticaria. Eur J Dermatol 2017;27:455-63.

19. Godse KV: Omalizumab in severe chronic urticaria. Indian J Dermatol Venereol Leprol 2008;74:157-8.

20. Maurer M, Rosén $\mathrm{K}, \mathrm{Hsieh} \mathrm{HJ}$, et al: Omalizumab for the treatment of chronic idiopathic or spontaneous urticaria. N Engl J Med 2013;368:924-35.

21. Kaplan A, Ledford D, Ashby $M$, et al: Omalizumab in patients with symptomatic chronic idiopathic/spontaneous urticaria despite standard combination therapy. J Allergy Clin Immunol 2013;132:101-9. 